\title{
UJI AKTIVITAS PENURUNAN KADAR ASAM URAT EKSTRAK ETANOL BUAH PINANG YAKI (Areca vestiaria) PADA TIKUS PUTIH GALUR WISTAR (Rattus norvegicus) YANG DIINDUKSI KALIUM OKSONAT
}

\author{
Christani Imanuel Jabriel Rambi ${ }^{1)}$, Edwin de Queljoe ${ }^{2)}$, Herny E. Simbala ${ }^{1)}$ \\ ${ }^{1)}$ Program Studi Farmasi FMIPA UNSRAT Manado, 95115 \\ 2) Jurusan Biologi FMIPA UNSRAT Manado, 95115
}

\begin{abstract}
An unhealthy diet in a high society protein, especially animal protein that contains a lot of purine, causes hyperuricemia (excess uric acid) to increase. The use of allopurinol that is too frequent or excessive can cause dangerous side effects. Based on these things, it is necessary to do research on antihyperuricemia substances that have high effectiveness and guaranted safety. This study aims to determine the potential for decreasing uric acid levels of areca nut fruit. This type of research as laboratory experiments using a Completely Randomized Design (CRD), with 5 types of treatment each treatment with 3 replications. Group 1 as a negative control was given induction of potassium oxonate, Group 2 as a positive control was given induction of potassium oxonate and allopurinol. Group 3-5 was trated with betel nut extract with different doses of 3,6 $\mathrm{mg} ; 7,2 \mathrm{mg}$ and 14,4 $\mathrm{mg}$. Based on the results of the ANOVA statistical test, serum uric acid levels were significantly different from $p=0,002(<0,05)$. The results of the ethanol extracts of pinangyaki fruit at doses of 3,6 mg / 200 gr BW, 7.2mg / 200gr BW and 14,4mg / $200 \mathrm{gr} \mathrm{BW}$ can reduce serum uric acid levels by anova statistical test with a confidence level of $95 \%$.
\end{abstract}

Keywords: Yaki Areca Fruit, Anthihiperurisemia, Anova

\begin{abstract}
ABSTRAK
Pola makan yang tidak sehat dalam masyarakat yang berprotein tinggi,terutama protein hewani yang banyak mengandung purin, menyebabkan penyakit hiperurisemia (kelebihan asam urat) semakin meningkat. Penggunaan allopurinol yang terlalu sering atau berlebihan dapat menimbulkan efek samping yang berbahaya. Berdasarkan hal-hal tersebut, perlu dilakukan penelitian mengenai zat antihiperurisemia yang memiliki efektivitas tinggi dan terjamin keamanannya. Penelitian ini bertujuan untuk mengetahui potensi aktivitas penurunan kadar asam urat dari Buah Pinang Yaki. Jenis penelitian ini ialah eksperimen laboratorium menggunakan Rancangan Acak Lengkap (RAL), dengan 5 macam perlakuan masingmasing perlakuan dengan 3 ulangan. Kelompok 1 sebagai kontrol negatif diberi induksi kalium oksonat), Kelompok 2 sebagai kontrol positif diberi induksi kalium oksonat dan Allopurinol. Kelompok3-5 diberi perlakuan ekstrak buah pinang yaki dengan dosis yang berbeda-beda yaitu 3,6 mg; 7,2 mg dan 14,4 mg. Berdasarkan hasil uji statistik Anova didapatkan kadar asam urat serum berbeda secara bermakna dengan $\mathrm{p}=0,002(<0,05)$. Hasil dari ekstrak etanol buah pinang yaki di dosis 3,6mg/200grBB, 7,2mg/200grBB dan 14,4mg/200grBB dapat menurunkan kadar asam urat serum dengan uji statistik Anova dengan tingkat kepercayaan $95 \%$
\end{abstract}

Kata kunci : Buah Pinang Yaki, Antihiperurisemia, Anova 


\section{PENDAHULUAN}

Pola makan dalam masyarakat yang mengandung protein tinggi,terutama protein hewani yang banyak memiliki kandungan purin dapat menyebabkan penyakit hiperurisemia (kelebihan asam urat) semakin meningkat. Penumpukan kristal umumnya terjadi pada jaringan sekitar sendi, sehingga menimbulkan rasa nyeri di daerah tersebut. Penyakit akibat hiperurisemia dikenal sebagai gout atau penyakit pirai (Pribadi dan Ernawati, 2010).

Gout di derita pada usia yang lebih awal dibandingkan dengan negara barat serta lebih sering menyerang laki-laki dibandingan wanita, sebab wanita lebih banyak memproduksi hormon estrogen yang mampu mencegah pembentukan asam urat. Sekitar $98 \%$ serangan asam urat pada wanita hanya terjadi pada usia manapouse. Kadar normal asam urat dalam darah adalah 3,47,0 mg/dL pada laki-laki dan 2,4-,5,7 mg/dL pada wanita (Hawkins dan Daniel, 2005).

Obat sintetik yang biasa dikonsumsi untuk mengobati asam urat oleh masyarakat adalah allopurinol yang menginhibisi aktivitas xantin oksidase. Xantine oksidase mengkatalisis oksidasi xantin menjadi asam urat. Penggunaan allopurinol yang terlalu sering atau berlebihan dapat menimbulkan efek samping, yaitu hepatitis, ruam pada kulit, berkurangnya jumlah sel darah putih, reaksi alergi, dan kerusakan hati ( Mo, et al. 2007).

Berdasarkan hal-hal tersebut, perlu dilakukan penelitian mengenai zat antihiperurisemia yang memiliki efektivitas tinggi dan terjamin keamanannya. Salah satu tanaman yang berpotensi untuk dimanfaatkan sebagai antihiperurisemia adalah Pinang Yaki. Beberapa penelitian telah membuktikan bahwa ekstrak etanol buah Pinang Yaki memiliki aktivitas antioksidan, karena adanya flavonoid (Simbala, 2006), yang dapat digunakan sebagai penghambat xantin oksidase dan sebagai penurun kadar gula darah (Aminah, 2014).

\section{METODOLOGI PENELITIAN}

\section{Waktu dan Tempat Penelitian}

Penelitian ini dilakukan di Laboratorium Penelitian dan Laboratorium Farmakologi Program Studi Farmasi, Fakultas Matematika dan Ilmu Pengetahuan Alam, Universitas Sam Ratulangi Manado yang dimulai pada November 2018 - Maret 2019.

\section{Alat dan Bahan}

Alat yang digunakan :Syringe $1 \mathrm{~mL}$, alat ukur asam urat (Autocheck), strip asam urat (Autocheck), Ayakan 200 mesh, oven,sonifikator, sonde oral, batang pengaduk, timbangan analitik (ADAM, KERN), gelas ukur (Pyrex), bekergelas (Pyrex), kertas saring, sarung tangan lateks, masker (SENSI Mask), botol sampel, gunting, blender, cawan petri (Pyrex), kandang.Bahan yang digunakan: Tikus putih jantan galur wistar (Rattusnovergicus) 15 ekor,buah pinang yaki (Areca vestiaria.), CMC (carboxymethylcellulose), aquades, etanol 96\%, pangan tikus wistar jantan (Rattusnovergicus) berupa beras jagung, allopurinol, kalium oksonat dan strip asam urat. 


\section{Prosedur Penelitian}

Pembuatan Ekstrak Buah Pinang Yaki

Ekstraksi dilakukan dengan metode ekstraksi dingin yaitu maserasi menggunakan pelarut etanol 96\%. Buah Pinang Yaki yang telah menjadi serbuk simplisia ditimbang dan dimasukkan ke dalam beker gelas kemudian diekstraksi dengan cara serbuk simplisia direndam dalam pelarut etanol $96 \%$ dan dibiarkan selama 5 hari kemudian disaring menggunakan kertas saring. Filtrat yang diperoleh dipekatkan menggunakan oven pada suhu $40^{\circ} \mathrm{C}$ sampai diperoleh ekstrak kental.

\section{Pembuatan Larutan CMC 1\%}

Larutan stok CMC 1\% dibuat dengan menimbang serbuk CMC sebanyak 1 gram kemudian dicampurkan dengan $100 \mathrm{~mL}$ aquades dihomogenkan dengan cara pemanasan menggunakan hot plate, kemudian didinginkan .Perbandingan aquades dengan CMC adalah 100:1 artinya didalam $100 \mathrm{ml}$ aquades terdapat 1 gram CMC.

\section{Pembuatan Larutan Uji}

Pembuatan larutan uji diawali dengan menimbang ekstrak kental Buah Pinang Yaki (Areca vestiaria.) sesuai dengan masing-masing dosis (18 mg;36 $\mathrm{mg} ; 72 \mathrm{mg})$, kemudian masing-masing ekstrak yang telah ditimbang dimasukan dalam labu ukur $10 \mathrm{~mL}$ dan ditambahkan larutan CMC 1\% sebanyak $10 \mathrm{~mL}$ dan disonifikasi sampai homogeny selama 30 menit. Setelah homogen, masing-masing dosis ekstrak di masukkan kedalam botol sampel dan diberi label. AV1 untuk ekstrak etanol Buah Pinang Yaki dengan dosis I; AV2 untuk ekstrak etanol Buah Pinang Yaki dengan dosis II; dan AV3 untuk ekstrak etanol Buah Pinang Yaki dengan dosis III.

\section{Pembuatan Larutan Allopurinol}

Larutan stok allopurinol dibuat dengan menimbang allopurinol sebanyak 17,5 mg kemudian dicampurkan dengan larutan CMC $1 \%$ sebanyak $10 \mathrm{~mL}$ didalam labu ukur kemudian dihomogenkan dengan sonifikator selama 5 menit. Setelah homogen disimpan dalam wadah dan diberi tanda.

\section{Pembuatan Larutan Kalium Oksonat}

Larutan stok dibuat dengan menimbang kalium oksonat sebanyak $112,5 \mathrm{mg}$ yang dicampurkan dengan aquades steril sebanyak $25 \mathrm{~mL}$ di dalam labu ukur kemudian disonikasi dengan sonifikator selama 30menit hingga larut, setelah dilihat cukup larut dimasukan dalam wadah dan diberi tanda.

\section{Pemberian Perlakuan}

Pemberian perlakuan untuk penelitian ini masing-masing konsentrasi menggunakan 3 hewan uji dengan total 15 ekor tikus jantan galur wistar.Semua hewan uji terlebih dahulu dibuat hiperurisemia dengan menginduksi kalium oksonat secara intraperitoneal kemudian ekstrak etanol buah Pinang Yaki diberikan sesuai dosis perlakuan secara oral dengan pensuspensi CMC $1 \%$ sebanyak $2 \mathrm{~mL}$ menggunakan alat penyekok oral (Sonde) dengan dispo.

\section{Pengambilan Sampel}

Hewan uji dipuasakan terlebih dahulu selama 18jam sebelum diambil darahnya. Pengambilan darah untuk 
pengujian kadar asam urat serum dilakukan sebanyak 5 kali yaitu setelah dipuasakan, setelah 1 jam diinduksi kalium oksonat, setelah 2 jam diinduksi kalium oksonat, dimana sudah termasuk 1 jam diberikan sediaan secara oral, setelah 4 jam dan 6 jam diinduksi. Sampel darah diambil melalui vena ekor mencit putih kemudian dianalisis kadar asam urat nya pada strip Autocheck.

\section{HASIL DAN PEMBAHASAN Pengamatan Kadar Asam Urat}

Pengukuran kadar asam urat dilakukan sebanyak 5 kali dalam waktu 6 jam dimana kadar asam urat diukur dengan interval waktu yang berbeda. Kadar asam urat puasa (t0) diambil setelah 18 jam tikus putih jantan dipuasakan untuk menghilangkan resiko kenaikan atau penurunan kadar asam urat yang dipengaruhi oleh pangan tikus.Pemeriksaan kadar asam urat selanjutnya dilakukan setelah 1 jam diinduksi kalium oksanat secara intraperitoneal. Hal ini dilakukan untuk melihat penyerapan kalium oksanat yang dipengaruhi oleh respon tubuh tikus. Di saat setelah pemeriksaan kadar asam urat, diberikan sediaan CMC 1\%, allopurinol, dan ekstrak dengan 3 dosis berbeda. 1 jam setelah nya dilakukan kembali pemeriksaan kadar asam urat karena menurut Huang et al (2008) puncak tertinggi efektivitas kalium oksonat di jam ke- 2 setelah pemberian kalium oksanat melalui intraperitoneal. Pemeriksaan kadar asam urat berikut nya dilakukan di jam ke- 4 dan ke- 6 setelah diinduksi kalium oksonat hal ini dilakukan karena menyesuaikan pengambilan data di jam ke 2. Pengukuran kadar asam urat dapat dilihat pada grafik berikut.
Tabel 1. Hasil pengukuran kadar asam urat tikus

\begin{tabular}{|c|c|c|c|c|c|c|}
\hline \multirow{3}{*}{ Perlakuan } & \multicolumn{6}{|l|}{ No } \\
\hline & \multirow{2}{*}{$\begin{array}{c}\text { Hewan } \\
\text { Uji }\end{array}$} & \multicolumn{5}{|c|}{$\begin{array}{c}\text { Kadar Asam Urat Tikus Selama } \\
\text { Pengujian }(\mathrm{mg} / \mathrm{dl})\end{array}$} \\
\hline & & to & $\mathrm{t} 1$ & $\mathrm{t} 2$ & $\mathrm{t} 4$ & t6 \\
\hline \multirow{4}{*}{$\begin{array}{l}\text { Kontrol } \\
\text { Negatif }\end{array}$} & 1 & 4,8 & 8,9 & 9,2 & 8.5 & 9,2 \\
\hline & 2 & 3,2 & 5,7 & 18,5 & 15,3 & 7,7 \\
\hline & 3 & 3,2 & 12,9 & 4,8 & 6 & 3,3 \\
\hline & $\begin{array}{l}\text { Rata- } \\
\text { rata }\end{array}$ & 3,7 & 9,1 & 10,8 & 9,9 & 6.7 \\
\hline \multirow{4}{*}{$\begin{array}{l}\text { Kontrol } \\
\text { Positif }\end{array}$} & 1 & 3,9 & 4,7 & 8 & 5,4 & 3,7 \\
\hline & 2 & 3,8 & 3,6 & 11,4 & 5,4 & 9,4 \\
\hline & 3 & 4,3 & 5,2 & 14 & 3,2 & 3,1 \\
\hline & $\begin{array}{c}\text { Rata- } \\
\text { rata }\end{array}$ & 4 & 4,5 & 11,1 & 4,6 & 5,4 \\
\hline \multirow{4}{*}{$\begin{array}{c}\text { EBPY } \\
3,6 \mathrm{mg} / \mathrm{BB}\end{array}$} & 1 & 7,1 & 8 & 6,8 & 5,1 & 3,1 \\
\hline & 2 & 3 & 3,3 & 3,2 & 17,3 & 3 \\
\hline & 3 & 3,4 & 7,2 & 11,5 & 3,1 & 3,2 \\
\hline & $\begin{array}{l}\text { Rata- } \\
\text { rata }\end{array}$ & 4,5 & 6,1 & 7,1 & 8,5 & 3,1 \\
\hline \multirow{4}{*}{$\begin{array}{c}\text { EBPY } \\
7,2 \mathrm{mg} / \mathrm{BB}\end{array}$} & 1 & 3,4 & 12,3 & 15,1 & 9,9 & 3,7 \\
\hline & 2 & 8,9 & 8,3 & 4,8 & 9,1 & 7 \\
\hline & 3 & 3,2 & 5,2 & 5,4 & 3 & 3,2 \\
\hline & $\begin{array}{c}\text { Rata- } \\
\text { rata }\end{array}$ & 5,1 & 8,6 & 8,4 & 7,3 & 4,6 \\
\hline \multirow{4}{*}{$\begin{array}{c}\text { EBPY } \\
14,4 \mathrm{mg} / \mathrm{BB}\end{array}$} & 1 & 6,6 & 5,7 & 14,7 & 7,3 & 4,3 \\
\hline & 2 & 5 & 4,7 & 4,8 & 4,3 & 5,3 \\
\hline & 3 & 4,7 & 4 & 8,2 & 3,2 & 3,3 \\
\hline & $\begin{array}{l}\text { Rata- } \\
\text { rata }\end{array}$ & 5,4 & 4,8 & 9,2 & 4,9 & 4,3 \\
\hline
\end{tabular}

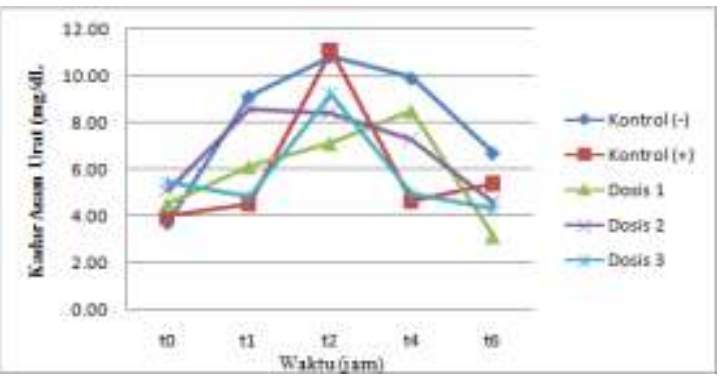

Gambar 1. Grafik rerata pengukuran kadar asam urat 
Dari hasil yang diperoleh pada Tabel 1 dan Gambar 1 terlihat bahwa perlakuan kontrol negatif yang diinduksi kalium oksonat dapat meningkatkan kadar asam urat darahmencapai puncak $10,8 \mathrm{mg} / \mathrm{dL}$ pada jam ke 2 (t2) dan terjadi penurunan kadar asam urat sedikit demi sedikit sampai 6 jam setelah pemberian induksi. Hal ini sesuai dengan penelitian sebelum nya (Huang et al.,2008). Allopurinol sebagai terapi farmakologi yang biasa digunakan secara klinis dapat menurunkan kadar asam urat secara bermakna setelah jam ke 2 (t2) hingga jam ke 6 (t6) dibandingkan dengan kelompok kontrol negatif. Efektivitas yang sama juga ditunjukkan oleh kelompok ekstrak buah pinang yaki. Ke tiga kelompok perlakuan dosis ekstrak ini $(200,400,800 \mathrm{mg} / \mathrm{kgBB})$ dapat menurunkan kadar asam urat darah secara bermakna dimulai dari jam ke 2 (t2) hingga jam ke 6 (t6). Hal ini menunjukkan bahwa kelompok perlakuan dosis ekstrak maupun kontrol positif dapat menghambat terjadinya hiperurisemia yang diinduksi kalium oksonat.Penurunan kadar asam urat oleh allopurinol telah diketahui melalui penghambatan pembentukan asam urat dari xantin (Katzung et al., 2012).

\section{Pengujian Statistik}

Untuk mendapatkan data yang lebih spesifik mengenai pengaruh ekstrak etanol buah pinang yaki terhadap penurunan kadar asam urat disetiap kelompok perlakuan dilakukan uji statistik ANOVA one way dan LSD.

\section{Uji One Way ANOVA}

Uji One Way Anova dilakukan untuk mengetahui pengaruh ekstrak etanol buah pinang yaki terhadap kadar asam urat pada tikus dengan hipotesis H0 tidak ada perbedaan yang bermakna antar kelompok, dan $\mathrm{H} 1$ terdapat perbedaan yang bermakna antara setiap kelompok.Uji Anova didapatkan kadar asam urat serum akhir tikus putih berbeda secara bermakna dengan $\mathrm{p}=0,002 \quad(<0,05)$ dimana hasil yang ditunjukkan hipotesis menolak $\mathrm{H0}$ dan menerima H1, maka didapatkan hasil bahwa efek penurunan kadar asam urat ekstrak etanol buah pinang yaki terdapat perbedaan yang signifikan $(\mathrm{p}<0,05)$.

Tabel 2. Hasil Uji One Way ANOVA

\begin{tabular}{|l|r|r|r|r|r|}
\hline & $\begin{array}{c}\text { Sum of } \\
\text { Squares }\end{array}$ & Df & $\begin{array}{c}\text { Mean } \\
\text { Square }\end{array}$ & F & Sig. \\
\hline Between & 74,586 & 4 & 18,647 & 6,277 &, 002 \\
$\begin{array}{l}\text { Groups } \\
\text { Within } \\
\text { Groups }\end{array}$ & 59,408 & 20 & 2,970 & & \\
Total & 133,994 & 24 & & & \\
\hline
\end{tabular}

\section{Uji LSD ( Least Significant Difference )}

Uji LSD dilakukan untuk mengetahui kelompok perlakuan mana yang memiliki perbedaan secara bermakna. Penurunan kadar asam urat serum oleh ekstrak etanol buah pinang yaki pada tikus putih lebih tinggi dari kontrol negatif dan lebih rendah dibandingkan dengan kontrol positif. Demikian pula dengan potensi penurunan kadar asam urat dibandingkan dengan kelompok perlakuan kontrol positif, ekstrak etanol buah pinang yaki dalam dosis 3,6mg dan 7,2mg/200gBB tersebut memiliki potensi penurunan kadar asam urat yang paling tinggi. 
Tabel 3. Hasil Uji LSD (Least Significant

\section{Difference)}

\begin{tabular}{|c|c|c|}
\hline Kelompok & P & Keterangan \\
\hline I - II & 0.071 & Tidak Berbeda \\
I - III & 0.000 & Berbeda Signifikan \\
I - IV & 0.033 & Berbeda Signifikan \\
I - V & 0.800 & Tidak Berbeda \\
II - I & 0.071 & Tidak Berbeda \\
II - III & 0.022 & Berbeda Signifikan \\
II - IV & 0.704 & Tidak Berbeda \\
II - V & 0.114 & Tidak Berbeda \\
III - I & 0.000 & Berbeda Signifikan \\
III - II & 0.022 & Berbeda Signifikan \\
III - IV & 0.049 & Berbeda Tidak Signifikan \\
III - V & 0.001 & Berbeda Signifikan \\
IV - I & 0.033 & Berbeda Signifikan \\
IV - II & 0.704 & Tidak Berbeda \\
IV - III & 0.049 & Berbeda Tidak Signifikan \\
IV - V & 0.055 & Tidak Berbeda \\
V - I & 0.800 & Tidak Berbeda \\
V - II & 0.114 & Tidak Berbeda \\
V - III & 0.001 & Berbeda Signifikan \\
V - IV & 0.055 & Tidak Berbeda \\
\hline
\end{tabular}

\section{KESIMPULAN}

Berdasarkan hasil penelitian yang didapatkan bahwa ekstrak etanol buah pinang yaki (Areca vestiaria) memiliki pengaruh terhadap penurunan asam urat serum tikus putih jantan galur wistar (Rattus norvegicus)padadosis I,II,dan III. Hasil uji ANOVA pada taraf uji 0,05 menunjukan hasil bahwa terdapat perbedaan bermakna antar kelompok perlakuan.

\section{SARAN}

Perlu adanya penelitian yang lebih mendalam mengenai mekanisme flavonoid yang terdapat dalam ekstrak buah pinang yaki terhadap penurunan asam urat.

\section{DAFTAR PUSTAKA}

Aminah, S. 2014. Uji Aktivitas Antidiabetes Ekstrak Etanol Kulit Buah Salak Salacca zalacca (Gaertner) Voss pada Mencit Swiss Webster Jantan yang Diinduksi Aloksan [Skripsi]. Bandung : Program Studi Farmasi. FMIPA. Universitas Islam Bandung.

Hawkins, D.W.,Daniel, W.Rahn. 2005. Pharmacotheraphy: A Pathophysiological Approach $3^{\text {rd }}$ Edition. London: Black Well Scientific Publication.

Huang, Shang, Zhang Li,Jiao. 2008. Hypouricemic Effects of Phenylpropanoid Glycosides Acteoside of Scrophularia ningpoensis on Serum Uric Acid Levels in Potassium OxonatePretreated Mice.The American Journal of Chinese Medicine. Vol. 36 (1): 149-157.

Katzung, B.G., Masters, S.B Trevor, A.J. 2012. Basic and Clinical Pharmacology. Edisi 12.Mc Graw Hill Medical, New York.

Mo,Shi Fu., Feng Zhou, Yao Zhong Lv, Qing Hua Hu, Dong Mei Zhang, Ling Dong Kong.2007. Hypouricemic Action of Selected Flavonoid in Mice: Structure Activity Relationship.Nanjing: Nanjing University.

Pribadi,F.W., Ernawati,D.A.2010. Efek Catechin Terhadap Kadar Asam Urat, C-Reaktive Protein (CRP) dan Malondialdehid Darah Tikus Putih (Rattus norvegicus) Hiperurisemia.Mandala of Health. 4(1): 39-46 
Simbala, H.E.I. 2006. Keanekaragaman

Floristik dan Pemanfaatannya

Sebagai Tumbuhan Obat di

Kawasan Konservasi II Taman

Nasional Bogani Nani Wartabone

(Kabupaten Bolaang Mongondow

Sulawesi Utara) Provinsi Sulawesi

Utara [Disertasi]. FMIPA IPB,

Bogor. 